\title{
Improving knowledge management is an urgent direction for the effective functioning and development of modern agriculture
}

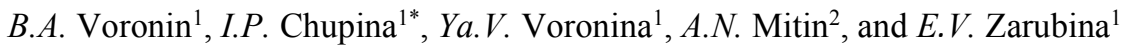 \\ ${ }^{1}$ Ural State Agrarian University, Yekaterinburg, Russia \\ ${ }^{2}$ Ural State Law University, Yekaterinburg, Russia
}

\begin{abstract}
Modern Russian agriculture functions in the context of new guidelines associated with the introduction of innovative scientific achievements into production based on the knowledge of world agricultural science and an interdisciplinary approach to scientific research in the agricultural sector. As noted by J. Harrigton and F. Vole in the book "Excellence in Knowledge Management" [1] - «knowledge is information transformed into the ability to act effectively». «Knowledge is a mixture of experience, practices, traditions, values, conceptual information, expert judgment and healthy intuition, providing a comprehensive platform for evaluating and implementing new experiences and information in an organization». Knowledge management consists in obtaining (extracting) knowledge and systematizing it by collecting, storing, searching and registering intellectual assets (copyright, patent, licenses, etc.). It is important to disseminate (transfer) the acquired new knowledge both within the corporation and in the external sphere, as well as in the education system in order to create an interactive learning environment.
\end{abstract}

\section{Introduction}

In a market economy, the commercialization of the acquired innovative knowledge is in demand as a way of reimbursing the costs of intellectualizing research and generating income from scientific activities, as well as future costs of carrying out work on the extraction of new knowledge necessary for implementation in production. In order to manage knowledge, it is necessary to create a management system in this area.

When creating a knowledge management system, processes should be developed to ensure [2]:

- the use of knowledge and actions based on it, as well as the operation of the system itself;

- transfer, distribution, deployment and exchange of knowledge;

- compilation, formalization, standardization and clarification of knowledge;

- assessment, validation and verification of knowledge;

- acquisition, accumulation, creation and discovery of knowledge;

\footnotetext{
*Corresponding author: irinacupina716@gmail.com
} 
- development, improvement, maintenance and updating of knowledge bases;

- storage, protection, conservation and archiving of knowledge.

The outlined list of activities and processes determines the formation of organizational and economic and legal mechanisms that contribute to the improvement of the knowledge management system.

The topic of the scientific article under consideration is relevant, since in the conditions of modern transformations in Russian agriculture, a new way is being formed, based on the knowledge and scientific achievements of world agricultural science. The introduction of new knowledge into the agricultural production of domestic agricultural commodity producers in the field of crop production, animal husbandry and other areas of agricultural activity will objectively require the perfection of knowledge management.

The study of the problem is confirmed by the presence of scientific publications in Russian and foreign editions. The expediency of developing the topic of this article is due to the analysis of the state of the knowledge management system in the Russian Federation.

The scientific novelty of the research is characterized by a new approach to the analysis and generalization of knowledge management practices in the field of agriculture and agroindustrial complex.

The purpose of this study is to identify the existing problems affecting the quality of knowledge management in the agricultural economy.

The objectives of the study are to analyze the effectiveness of knowledge management mechanisms in the agricultural sector.

\section{Materials and Methods}

The article uses statistical data of the federal and regional levels. Methods of analysis and synthesis were used to summarize the research results. The method of a systemic integrated approach is used in proposals for improving knowledge management as an urgent direction for the effective functioning and development of modern agriculture.

\section{Results and Discussion}

The development of agriculture in order to obtain agricultural products, ensuring food security and food independence of the Russian state, as well as an increase in the export of agricultural products to the world agri-food market, will require a transition to a new technological mode based on knowledge of scientific achievements in the field of agricultural production. The following legal acts are focused on organizing the solution of such tasks: Decrees of the President of the Russian Federation No. 204 of 05/07/2018 "On national goals and strategic objectives of the Russian Federation and No. 474 of July 21, 2020" On the national development goals of the Russian Federation for the period up to 2030 " [3], as well as the Doctrine of Food Security of the Russian Federation dated January 21, 2020 [4], Decree of the President of the Russian Federation No. 350 dated July 21, 2016 "On measures to implement scientific and technological policy in the interests of agriculture" [5], Federal scientific and technological program for the development of agriculture for 2017-2025 [6], Forecast of scientific and technological development of the agro-industrial complex of the Russian Federation for the period up to 2030 [7]. To these political and economic documents, it is necessary to add a list of regulatory legal acts that determine guidelines for the development of scientific research in the field of digitalization, robotization, information technology, a "green" agricultural economy and the greening of agricultural activities, other areas of "smart" agriculture that require scientific research. provision and new scientific knowledge that has never previously existed in Russian agriculture. 
At present, domestic agricultural production can successfully function in conditions when employees of an agricultural organization have the necessary level of theoretical knowledge and, on this basis, form professional competencies that allow them to work productively and successfully solve the problems of economically effective development of the organization.

Today, the existing laws and bylaw normative legal acts that establish strategic goals for the development of scientific research and the acquisition of new knowledge operate in isolation, which does not contribute to effective and high-quality law enforcement.

This circumstance will require the creation of a knowledge management system and, in general, systematization, in our case, of agricultural legislation.

It is also necessary to take into account the factor of further formation of knowledge through the creation of artificial intelligence and the digital transformation of the agricultural economy. The listed areas of intellectualization of Russian agricultural production will require the creation of new conditions for obtaining the necessary knowledge by the existing personnel and specialists of the agricultural organization, otherwise it will be impossible to achieve progress in production and economic activities. As an element of the knowledge management system, it is necessary to train employees of the organization in new technologies and methods of farming. Responsible tasks are facing the system of agricultural education, since students already within the walls of the university must prepare themselves for work in the conditions of intellectualized production in agricultural organizations. Serious attention in the educational process should be paid to the study of mathematics and computer science.

Students should pay more attention to the study and development of practical skills in the field of selection and seed production of agricultural crops, selection and breeding in animal husbandry and poultry farming. The training of future veterinary workers should be especially organized, moreover, it is desirable for students to research the development of veterinary drugs based on biochemical production methods, which would allow them to not use synthetic chemical drugs and stimulants in the future.

The Smart Farm is a fully robotic facility that conducts a feasibility study. For example, this analysis points to the economic feasibility of breeding certain breeds of farm animals. Milking robots are now in use all over the world.

Digital technologies ensure the competitiveness of agriculture and have the ability to attract investment. They are needed to increase milk yield and improve the quality of dairy products. if the average milk productivity of cows is 5,000 liters per year, then through the introduction of modern technologies it is possible to achieve a result of up to 12,000 liters per year. Another plus is the fact that the production process can take place without the presence of an operator. Also, sensors have been developed and introduced into production that monitor the physiological state of animals and detect any problems in them at the early stages of the disease, when the animal can be provided with timely assistance. With the help of such sensors, the incidence of mastitis is reduced by at least $60 \%$. The quality of dairy products is also increasing by about $30 \%$.

A smart farm also involves automated feed production, automated feeding, and microclimate determination. Feedback with consumers using information and analytical blocks is also important.

But not only robots on farms are being actively implemented in agriculture. "Smart equipment" is constantly being improved during sowing, irrigation, in the collection and sorting of agricultural products. For this, precision sowing technologies are used. Sensor data helps to identify soil quality, soil density and moisture and fertility levels. Therefore, an increase in yields is guaranteed here to a greater extent than without the use of new technologies. 
In the near future, one person will be able to sow several fields, watching the work of new agricultural machines via video - broadcast with a digital control panel.

Subsoil drip irrigation is also not now a new technology, although it is not yet used in all farms. IoT - sensors monitor soil moisture levels and plant health. This process is also automatic without the intervention of workers.

New technologies have also advanced significantly in agriculture, where the BoniRob field robot moves in the field using a satellite, where there are built-in cameras. This robot removes weeds and evaluates young seedlings. Destroys weeds and the Smart Farm automated cultivator. It distinguishes crops from weeds and destroys the latter. Such robots allow farms and agricultural organizations to do without a large number of workers.

With the help of machines and robots, you can now harvest vegetables and fruits. Panasonic has developed a tomato picking robot. Using cameras and a color algorithm, the robot recognizes ripe fruits. There are robots for picking apples, where, using computer vision, the robot also recognizes ripe fruits.

As for drones, they are increasingly used not only in agricultural enterprises, but also in farms. Drones recognize soil quality, assess crop health. With the help of field surveys, it is possible to plan planting on certain plots of land, to plan irrigation works. Drones are now good helpers in planting and irrigating plants. Teams of scientists are now working on such drones that can use compressed air to scatter capsules of seeds and fertilizers. Such drones will play a huge role in reforestation. In addition, drones will help to plant plants in suitable areas in favorable soil, where conditions for rapid growth and good yields exist.

In China, drones are now actively used to spray plants. But drones have one drawback. They can stay in the air for no more than one hour, and then they need to recharge the battery. And the prices for drones are quite high, which is the second disadvantage. Each of them costs at least 15 thousand dollars. And the cheaper types of drones do not perform the high-quality field surveys that farmers need.

Nowadays, artificial intelligence is being used more and more actively in agriculture. If in 2010 there were no more than 20 companies in the world that supplied new technologies for agriculture, now the number of such companies has increased tenfold. The United States is recognized as the most advanced country where new technologies are being actively introduced. This country occupies more than $45 \%$ of the use of new technologies in agriculture on the world market. American farmers are actively using drones, which conduct soil analysis, and use satellite images. Countries such as Germany, India and China are no less actively using new technologies. In Russia, the smart farming market is only $1.5 \%$ of the global market.

Of course, not all farms will be able to afford a complete re-equipment with modern technologies. This can only be done by large organizations. For example, in Ireland, in 2014, the state program "Smart Farming" came into effect. More than 2000 farms take part in this program. The program provides for various scenarios for the use of new technologies and reduction of environmental pollution from the activities of agricultural enterprises [8], [9].

Now let's dwell on new technologies in the field of precision farming. Precision farming technologies are based on navigation and telemetry systems, remote sensing of lands, and differential fertilization. In Russia, the domestic navigation console "Azimut - 1" is used. It is designed to measure the worked area of the field. There are also agronavigators for night cultivation in the fields. The advantage of this innovation is that it requires a relatively small amount of fuel and completely eliminates manual labor when applying fertilizers and chemicals in the fields. They also help in areas of risky farming.

Geographic information systems are also firmly included in our life. Domestic geoinformation systems include GIS "Panorama AGRO", "Geoplan", "GEO - Agro" and some others. These companies are engaged, in particular, in the simulation of sensor 
sensors that are designed to measure soil properties. Sensors detect weeds and pests as well as plant diseases.

CropX Ltd, an agricultural company from Israel, develops cloud-based software solutions to increase crop yields. Built-in sensors monitor soil conditions and transmit data to analysts. Among domestic companies, one can single out JSC "Component", which is engaged in vehicle monitoring, analysis of agricultural land and management in animal husbandry.

All countries are now developing innovative equipment for agricultural organizations and farms. The novelty of this article is the fact that now at the Ural State Agrarian University master classes are being held for farmers not only in the format of lectures, but also online consultations for agricultural enterprises. Farmers, using smartphones, receive accurate information about field operations - when to water, fertilize and harvest. On the basis of such a program "Smart Farm", which is headed by Doctor of Law, Professor B. Voronin, farmers plan their work, allocating resources more rationally. But not every farmer has access to the Internet. Therefore, the authors propose to develop a program based on the data of Internet resources that would inform farmers about recommendations for the production of products, information about the sale of products in different regions, in order to help manufacturers to properly organize the sale of their products. Research is also being developed on the results of land use on farms of different sizes in the Sverdlovsk region. This monitoring will help create a soil data management system. In the future, it is planned to attract other farmers in the region to attend such classes in the format of lectures and online conferences.

The use of clean water for agricultural needs is also acquiring great importance. In the world, more than $65 \%$ of clean water is consumed in agriculture. And more than half of that figure is wasted. Innovative systems solve this problem by alerting farmers of leaks. The Ocean Reef Group is already experimenting with growing agricultural products under water. Experts plant cabbage, lettuce, beans and strawberries with water. And these innovative inventions also need to be conveyed to our farmers so that they know about the existence of such technologies. Of course, now in the Sverdlovsk region in the near future we will not be able to grow strawberries under water on our farms. But in the future it will be quite possible that this too.

Currently, at the Ural State Agrarian University, farmers have access to such programs as "Improvement and optimization of feeding highly productive cows. The program is designed for 72 hours and includes such issues as the characteristics of the feed base, the rationing of feeding cows, the importance of nutrients for milk productivity and the chemical composition of feed. Also, farmers need to know about the sanitary and hygienic indicators of dairy products. And these issues are being implemented by the program "assessment of physical - chemical and sanitary - hygienic indicators of milk and dairy products." The program is also designed for 72 hours, where, during lectures and practical classes, questions about the physical and chemical properties of milk are considered, recommendations are given on the storage and transportation of dairy products. Describes the sampling of dairy products. There are also a number of other programs implemented at the university, where the issues of milk production technology in modern conditions are highlighted, there is an acquaintance with the Selex program for organizing breeding work at enterprises. Students are also introduced to the functions of accounting.

The innovative program is the program for the production technology of pheasants and ostriches. Here, much attention is paid to the environmental aspects of poultry farming. The program for the production of cheeses in the conditions of small-scale farming is also relevant at the moment, where the acquaintance with the technology of rennet cheeses takes place, the technologies of cheese production are studied and then master classes on the production of cheeses are held. Also, a program has been developed for advanced 
technologies for organizing machine milking. Here they introduce the methods and methods of milking cows, talk about the care and preparation of milking equipment.

For plant growing, a program for maintaining a highly aesthetic and productive fruit garden has been developed and is being implemented. The program introduces the timing and methods of planting fruit plants, with the life and annual cycles of development of perennial plants, as well as with such environmental factors as light, soil, temperature and water supply for fruit trees. In addition to this program, the university implements a professional retraining program on modern technologies in agronomy. The program provides for the study of issues such as soil composition, phytopathology and chemical plant protection products, breeding and seed production, as well as crop cultivation technology.

The program for the production of organic products is currently becoming the most urgent. It discusses the effectiveness of organic farming, biological methods of plant protection, fertilization in organic crop production.

\section{Conclusion}

The topic of improving knowledge management is relevant for the functioning and development of agricultural production, because without the transition to a new way, the perspective of the agricultural sector of the economy, based on knowledge, is more than problematic.

A new era is coming to the agriculture of the Russian Federation, and this circumstance will require a scientific, technological and technical revolution, because otherwise it will be impossible to exist in conditions of global competition in the agri-food market. The competitiveness of a modern agrarian organization will be assessed by the results of agricultural production based on new knowledge and achievements in the field of plant breeding and livestock breeding.

The state program "Development of education for 2013 - 2020", approved by the Decree of the Government of the Russian Federation on 15/04/2014, No. 295 emphasizes that improving the quality and efficiency of education is a priority area of state policy. Normative legal acts on experimental and innovative activities are also adopted at the regional level [10]. These include the Order of the Moscow Department of Education dated June 24, 2005 No. 339 "On Approval of the Regulation on the Organization of Experimental and Innovative Activities in the Education System of the City of Moscow" [11], Resolution of the Government of the Sverdlovsk Region dated September 18, 2019 No. 588 - PP "On approval of the Strategy for the development of education in the Sverdlovsk region for the period up to 2035" [12-13], Law of the Sverdlovsk region dated July 15, 2013 No. 78-OZ "On education in the Sverdlovsk region" [13, 14]. Federal and regional laws and regulations indicate that the development of innovative education is a priority in public policy.

\section{References}

1. J. Harrington, F. Vole. Knowledge management excellence. The art of improving knowledge management RIA "Standards and Quality" 272 (M., KnoRus, 2008)

2. Decree of the President of the Russian Federation No. 204 of 05/07/2018 "On national goals and strategic objectives of the development of the Russian Federation for the period up to 2024", Electronic portal of legal information (2018)

3. Decree of the President of the Russian Federation No. 474 of July 21, 2020 "On the national development goals of the Russian Federation for the period up to 2030", Electronic portal of legal information (2020) 
4. Doctrine of food security of the Russian Federation Decree of the President of the Russian Federation No. 20 of January 21, 2020, Collected Legislation of the Russian Federation, 4, 345 (2020)

5. Decree of the President of the Russian Federation No. 350 dated July 21, 2016 "On measures to implement scientific and technological policy in the interests of agriculture", Separate publication of the Ministry of Agriculture of the Russian Federation, (M., FGBNU "Rosiifiragrotex", 2017)

6. Federal scientific and technological program for the development of agriculture for 2017-2025. approved Decree of the Government of the Russian Federation No. 996 of 25.08.2017,Separate publication of the Ministry of Agriculture of the Russian Federation (M., FGBNU "Rosiifiragrotex", 2017)

7. Forecast of scientific and technological development of the agro-industrial complex of the Russian Federation for the period up to 2030. approved by order of the Ministry of Agriculture of the Russian Federation (2017)

8. O. Rubaeva, E. Pogartseva, E. Kot, T. Nikitina, Journal of Environmental Management and Tourism, 9, 7 (31), 1513 - 1525 (2018)

9. O. Rubaeva, Advances in Intelligent Systems Research, 167, 59 - 63 (2019)

10. State program "Development of education for 2013 - 2020", approved by the Decree of the Government of the Russian Federation on 15.04.2014 No. 295 https://sudact.ru/law/rasporiazhenie-pravitelstva-rf-ot-22112012- n-2148-r /gosudarstvennaia-programma-rossiiskoi-federatsii-razvitie /

11. Order of the Moscow Department of Education dated June 24, (2005) No. 339 "On approval of the Regulation on the organization of experimental and innovative activities in the education system of the city of Moscow" https://www.alppp.ru/law/obrazovanie-nauka-kultura/obrazovanie/1/prikaz-departam enta-obrazovanija-g - moskvy-ot-24-06-2005--339.html

12. Decree of the Government of the Sverdlovsk region of September 18, (2019) No. 588 PP "On approval of the Strategy for the development of education in the Sverdlovsk region for the period up to 2035 " https://docs.cntd.ru/document/561550824

13. Law of the Sverdlovsk region of July 15, (2013) No. 78-OZ "On education in the Sverdlovsk region" https://rg.ru/2013/07/18/sverdlovsk-zakon78-reg-dok.html

14. A.N. Mitin, Agrarian Bulletin of the Urals, 12-2(167), 40-46 (2017) 